Research articles

\title{
Beliefs about school mathematics vs. university mathematics and beliefs about teaching and learning in different contexts of students' achievement
}

\author{
Safrudiannur. ${ }^{1}$ P.M. Labulan ${ }^{1}$, Suriaty ${ }^{1}$, Benjamin Rott ${ }^{2}$
}

\begin{abstract}
Abstrak Penelitian kuantitatif dengan 206 calon guru matematika ini bertujuan untuk menginvestigasi efek dari dua faktor yang mempengaruhi keyakinan para calon guru: (1) konteks yang berhubungan dengan capaian siswa dan (2) perbedaan karakteristik antara matematika sekolah dan matematika universitas. Hasil penelitian menunjukkan bahwa para calon guru tersebut (1) memiliki keyakinan yang berbeda tentang bagaimana mengajar dan belajar matematika di dalam konteks yang berbeda, yaitu antara kelas yang didominasi oleh siswa-siswa capaian tinggi dan kelas yang didominasi oleh siswa-siswa capaian rendah, dan (2) memiliki keyakinan yang berbeda antara matematika sekolah dan matematika universitas. Menariknya, jika dibandingkan dengan keyakinan tentang matematika sekolah, keyakinan para calon guru tentang matematika universitas ternyata lebih baik korelasinya terhadap keyakinan mereka tentang bagaimana mengajar dan belajar di dua konteks kelas tersebut. Selanjutnya, artikel ini akan mendiskusikan implikasi dari korelasi yang lebih baik tersebut terhadap pendidikan para calon guru matematika.
\end{abstract}

Kata kunci Keyakinan, Belajar mengajar matematika, Matematika sekolah, Matematika universitas, Capaian siswa

\begin{abstract}
This quantitative study with $n=206$ participants (mathematics pre-service teachers from Indonesia) investigates the effect of two factors on pre-service teachers' beliefs: (1) contexts related to students' achievement as well as (2) the differences between school mathematics and university mathematics. The results of this quantitative study show that the participants (1) have different beliefs about teaching and learning of mathematics in different contexts of students' achievement (a class dominated by high-achieving students vs. a class dominated by low-achieving students) and (2) have different beliefs about school mathematics and university mathematics. Interestingly, compared to their beliefs about school mathematics, the pre-service teachers' beliefs about university mathematics correlate better with their beliefs about teaching and learning in different contexts of students' achievement. The implication of the better correlations for the pre-service teacher education are further discussed.
\end{abstract}

Keywords Beliefs, Teaching and learning of mathematics, School mathematics, University mathematics, Students' achievement

\section{Introduction}

Understanding teachers' beliefs, including pre-service teachers' (PSTs') beliefs is essential for education (Pajares, 1992); one of the reasons for this importance is that several studies have found a strong relationship between beliefs and practices (see Philipp, 2007 and Thompson, 1992

\footnotetext{
${ }^{1}$ Universitas Mulawarman, Jln. Kuaro Samarinda 75119, Indonesia, safrudiannur@fkip.unmul.ac.id

${ }^{2}$ University of Cologne, Cologne, Germany
} 
for overview of research on beliefs). Some studies have already explored the field of PSTs' beliefs, such as PSTs' beliefs about mathematics, their beliefs about teaching and learning as well as the relationship between beliefs (e.g., Briley, 2012; Dede \& Uysal, 2012; Rejeki \& Sugiyanti, 2015; Zakaria \& Musiran, 2010).

However, based on our review, those studies only explore PSTs' beliefs about teaching and learning without considering the influence of contexts on PSTs' beliefs about teaching and learning. Whereas, research has shown that beliefs about teaching and learning are affected by contexts (Buehl \& Beck, 2015; Leatham, 2006). For example, one of the contexts which may influence beliefs is related to students' achievements. The studies conducted by Beswick (2018), Larina and Markina (2020), Raymond (1997), and Zohar, Degani, and Vaaknin (2001) reveal that students' achievements (or abilities) in mathematics may affect teachers' beliefs about teaching and learning. Therefore, in this study, we will investigate whether contexts related to students' achievements also influence PSTs' beliefs about teaching and learning.

Furthermore, the studies exploring PSTs' beliefs about mathematics only explore what the PSTs believe about mathematics, neglecting possible difference between the nature of mathematics at school level (school mathematics) compared to mathematics at university level (university mathematics). Whereas, other studies (for example: Beswick, 2012) have revealed that teachers may hold different beliefs about school mathematics and pure mathematics (pure mathematics is usually learned at universities, and therefore, in this paper pure mathematics is also subsumed under the term university mathematics). Geisler and Rolka (2021) highlight the possibility that university students differ school mathematics from university mathematics because of the different nature of school mathematics and university mathematics. Therefore, in this study, we will also explore whether PSTs have different beliefs of both types of mathematics.

If a PST has different beliefs about mathematics teaching and learning in different contexts of students' achievements and different beliefs about school mathematics and university mathematics, then this condition raises a question regarding the relationship between beliefs about mathematics and beliefs about mathematics teaching and learning. In this study, we will also investigate the correlation between PSTs' beliefs about school mathematics and university mathematics with their beliefs about teaching and learning in different contexts of students' achievements.

Overall, the research questions of this present study are: (1) Do PSTs have different beliefs about teaching and learning in different contexts of students' achievements (a class dominated by high-achieving students [an HA class] vs. a class dominated by low-achieving students [an LA class])? (2) Do PSTs have different beliefs about school mathematics and university mathematics? and (3) Are there correlations between PSTs' beliefs about mathematics and their beliefs about mathematics teaching and learning? We illustrated the research questions in Figure 1 to assist the readers of this paper in better understanding our study.

\section{Theories to measure PSTs' beliefs}

\section{Beliefs about the nature of mathematics and the association with the way of teaching}

Speaking about PSTs' beliefs, we refer to the definition by Philipp (2007): "beliefs as psychologically held understandings, premises, or propositions about the world that are thought to be true" (p. 259). Based on the definition, one may have various beliefs about mathematics since they may see mathematics with different views. We then use Ernest (1989a, 1989b)' concepts regarding three views in mathematics called the instrumentalist view, the Platonist view, and the problem-solving view of mathematics as well as his concepts about the association of the three views with the way how teachers teach mathematics. 


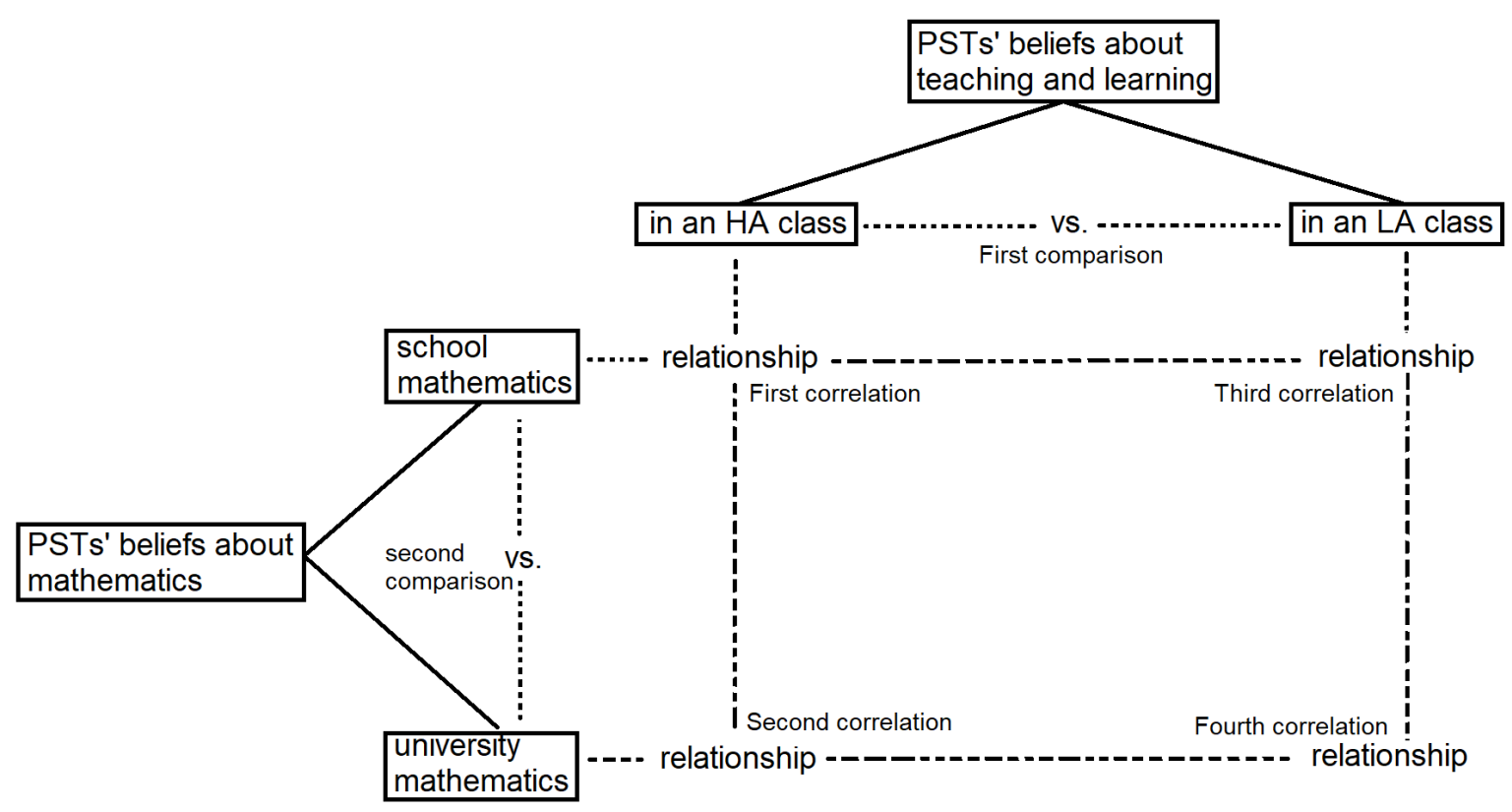

Figure 1. The framework of this following study

Ernest explains that teachers who hold the instrumentalist view will see mathematics as a toolbox consisting of an accumulation of formulas, rules, procedures or skills which can be used everywhere; teachers who hold the Platonist view will see mathematics as a static but unified body of certain knowledge, and therefore, concepts in mathematics are interrelated and interconnected logically; and teachers who hold the problem-solving view will see mathematics as not a finished product, but a process of human creation and invention in solving problems, and therefore, mathematics as always expanding and being open to revision. Beside Ernest, Dionne (1984) as well as Törner and Pehkonen (1998) also suggest three views about mathematics. Dionne expresses the traditional perspective (seeing mathematics as a collection of rules and skills), the formalist perspective (seeing mathematics as a formal knowledge which is structured, rigorous, and logic), and the constructivist perspective (seeing mathematics as a constructive process which means that mathematics is not transmitted but should be reconstructed by learner. Törner and Pehkonen expresses the toolbox aspect (seeing mathematics as a large toolbox consisting of a set of rules, procedures, and formulas), the system aspect (seeing mathematics as a formal system emphasizing clear and concise language), and the process aspect (seeing mathematics as a human process).

Although Ernest, Dionne, as well as Törner and Pehkonen use different names, their conceptual views about mathematics are similar. Törner and Pehkonen (1998) draws the correspondence of their conceptual views: the instrumentalist view $\sim$ the traditional perspective $\sim$ the toolbox aspect, the Platonist view $\sim$ the formalist perspective $\sim$ the system aspect, and the problem-solving view $\sim$ the constructivist perspective $\sim$ the process aspect (the symbol " $\sim$ " means the correspondence). Thus, although we use Ernest's conceptual views to investigate PSTs' beliefs primarily, we still use other conceptual views from Dionne and Törner and Pehkonen in the interpretation of PSTs' beliefs.

Further, Ernest also explains that the three beliefs about the nature of mathematics can be associated with models of teaching mathematics. Teachers who hold the instrumental view will likely act as instructors who demonstrate mathematical formulas and skills correctly, and students are expected to master the formulas and skills from the demonstrations. Teachers who hold the Platonist view will likely act as explainers who explain concepts clearly, and students are expected to understand the concepts from the explanations. Teachers who hold the problemsolving view will likely act as facilitators who encourage students to solve problems with their 
own strategies, and students are expected to actively construct their understanding from problem-solving activities. Further, as facilitators, the teachers are not only confident to engage students in problem-solving activities but also confident to engage students in problem-posing activities.

\section{Factors affecting PSTs' beliefs}

\section{Contexts related to students' achievements}

As we pointed out in the introduction, research has shown the influence of students' achievements on teachers' beliefs about teaching and learning. Schoenfeld (2015) argues that teachers may differ their beliefs about teaching and learning between an ordinary class and an honour class (i.e., a class with many high-achieving students). The study conducted by Zohar et al. (2001) shows that teachers may consider teaching styles that foster higher order thinking skills being appropriate only for honour classes and not appropriate for ordinary classes.

We argue that the differentiation of beliefs may also take place on PSTs' beliefs. For example, Elisa, a new math teacher participating in the study of Safrudiannur and Rott (2019), acknowledged that when she was a student at school, she had friends who had good achievements in mathematics. She found that they could understand mathematics fast, and therefore, she imagined that it would be easy to teach them mathematics. Like Elisa, other PSTs may also have similar experiences at schools in having peers with high- or low-achieving in learning mathematics. Therefore, if Pajares (1992) is right that PSTs' experiences in school contribute to their beliefs, it is possible that the condition of students' achievements affects the PST's beliefs about teaching and learning.

\section{The different nature between school mathematics and university mathematics}

As we pointed out int the introduction, the different nature between school mathematics and university mathematics may affect PSTs' beliefs about mathematics. Unlike school mathematics which emphasizes schematic calculations in solving mathematical tasks, university mathematics mostly emphasizes proofs (Tall, 2008) which the schematic calculations cannot be used to do the proofs (Geisler \& Rolka, 2021).

Further, the explanation of Leong, Cheng, Toh, Kaur, and Toh (2021) also indicates the different nature of school mathematics and university mathematics. The authors explain that students may learn formulas in school mathematics such as a formula to find the area of twodimensional shapes or Pythagoras' theorem. Those formulas help students to solve mathematical tasks. However, Leong et al. argue that the term formula is less common in mathematics as a discipline (i.e. university mathematics). In university mathematics, mathematical contents are developed from axioms, definitions, theorems (including lemmas and corollary). Instead of engaged on how to use mathematics like in school, university students are engaged in learning mathematics emphasizing the use of rigorous arguments involving axioms and definitions (and perhaps, also previously proved theorems) to prove theorems.

The different emphasis between school mathematics and university mathematics may cause university students to have difficulties in learning university mathematics (Di Martino \& Gregorio, 2019; Geisler \& Rolka, 2018). In turn, those difficulties may cause university students (including PSTs) to differ school mathematics from university mathematics.

\section{Methods}

To answer the research questions, we conducted this following study.

\section{Participants}

The participants of this quantitative study are 206 PSTs (66 of them in the 1st semester, 80 in the 3 rd semester, 48 in the 5 th semester, 8 in the 7 th semester, 4 in the 9 th semester) at the 
Department of Mathematics Education of the Mulawarman University, Indonesia. They responded the instrument (explained in the next section) used in this study neither in a specific course nor after a specific course.

\section{The instrument}

We have developed an instrument for studying Teachers' Beliefs on Their Practices (called the TBTP, see Safrudiannur, 2020 as well as Safrudiannur \& Rott, 2018, 2021 regarding its validity and reliability). In this quantitative study, we used an adapted version of the TBTP which is more appropriate for studying PSTs' beliefs. There are three differences between the TBTP and the adapted version. Firstly, there are three themes in the TBTP, namely "teaching and learning of mathematics", and "teaching and learning of problem solving", "the nature of mathematics". In the adapted version of the TBTP, with "teaching and learning of problem solving" being omitted (see Table 1). Secondly, the theme "teaching and learning of mathematics" of the TBTP only consists of four items focusing on a formula to calculate the area of a trapezoid. In order to get a better insight into PSTs' beliefs about teaching and learning of mathematics, we added more four items in the adapted version of the TBTP which address another typical formula from mathematics lessons. The formula is to find the equation of a straight line through two points (see Table 1 specifically items 5-8). Thirdly, we added two additional items in the theme "the nature of mathematics" in the adapted version of the TBTP (see Table 1 specifically items 9-12). The addition aims to investigate whether participants differ school mathematics from university mathematics.

All items are rank-then-rate items with each item containing three statements: Statement A (always associated with the instrumentalist view), Statement B (always associated with the Platonist view) and Statement C (always associated with the problem-solving view). To respond to a rank-then-rate item, participants must order the three statements of the item by assigning a rank 1 (the most), 2, or 3 (the least). Then, they must rate each of them based on their rank (as examples, see Figure 2 and Figure 3).

Table 1. The notes, items, and statements of the revised TBTP

\section{The structure of the TBTP}

General note: When you were a student, you might have friends in your classes who have high achievement and low achievement in mathematics. Consider these definitions:

A high-achieving (HA) student is a student who generally shows good understanding in math lessons and regularly has high scores in math tests.

A low-achieving (LA) student is a student who generally does not show good understanding in math lessons and often has low scores in math tests.

To answer all questions, you need to IMAGINE that you are a teacher and have a class dominated by HA students and a class dominated by LA students.

\section{Theme 1: Teaching and learning of mathematics.}

Note: You will have a lesson to find the area of a trapezoid whose lengths of its parallel lines and height are known (see the figure below). To find its area, one can divide the trapezoid to be several triangles, rectangles, or parallelograms, or simply use a formula presented below (called as the area formula).

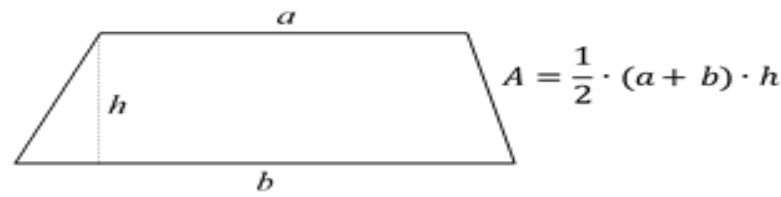


When you have the lesson in a class dominated by HA/LA students, what do you think that is o $\sim$ important for YOU as a teacher?

\& A. You demonstrate how to use the area formula correctly by giving some examples.

B. You explain concepts related how to get the area formula.

C. You let students find the area of a trapezoid by their own ways.

When you have the lesson in a class dominated by HA/LA students, what do you think is important for the STUDENTS?

\&ै $\downarrow$ A. They memorize and use the area formula correctly.

$\underset{ \pm}{\infty}$ B. They can understand concepts underlying the area formula from your explanation.

C. They can find the area of a trapezoid by using their own strategies.

Note: You will teach a lesson to find the equation of a straight line through two points $\left(x_{1}, y_{1}\right)$ and $\left(x_{2}, y_{2}\right)$. To find the equation, one can draw the graphic of the line and then use other points in the line as auxiliary points, or use the gradient of the line, or simply use a formula presented below (called as the line formula).

$$
\frac{y-y_{1}}{y_{2}-y_{1}}=\frac{x-x_{1}}{x_{2}-x_{1}}
$$

When you have the lesson in a class dominated by HIGH/LOW ability students, what do you think that is important for YOU as a teacher?

I $\&$ A. You demonstrate how to use the line formula, and then give students some examples as a in practice to use the formula correctly.

B. You explain concepts related how to get the line formula.

C. You let students use their own ways to find the equation.

When you have the lesson in a class dominated by HIGH/LOW ability students, what do you of $\infty$ think is important for the STUDENTS?

$\underset{ \pm}{\infty}$ A. Students can use the line formula correctly and fluently.

$\pm \sim$ B. They can understand concepts underlying the line formula from your explanation.

C. Students can find the equation by their own strategies.

\section{Theme 2: The nature of mathematics}

Note: The contents of SCHOOL mathematics can be divided into several sub-domains such as numbers, algebra, geometry and measurements, statistics, and probability. The classification of the contents of UNIVERSITY mathematics are complex, for example, classical algebra, linear algebra, abstract algebra, number theory, field theory, algebraic geometry, discrete geometry, differential geometry, analysis real, differential equations, calculus, statistics, probability theory, combinatoric, numerical analysis, game theory, etc.

What do you think of the contents of SCHOOL mathematics /UNIVERSITY mathematics?

A. SCHOOL/UNIVERSITY mathematics is an accumulation of facts, rules, and skills, which are useful for human life.

B 을 The contents of SCHOOL/UNIVERSITY mathematics are interrelated and logically

Ð $\nsim$ connected within an organisational structure.

C. Mathematics is a dynamic process of human activities. Thus, the contents of SCHOOL/UNIVERSITY mathematics expand and change to accommodate new developments.

What do you think of the truth of the contents of SCHOOL/UNIVERSITY mathematics?

A. The truth of SCHOOL/UNIVERSITY mathematics is absolute. Its contents are free of I ambiguity and conflicting interpretations.

Ð $\nsim$. Ideas in mathematics are pre-existing; humans just discover them. Thus, the truth-value of SCHOOL/UNIVERSITY mathematics is objective, not determined by humans.

C. The contents of SCHOOL/UNIVERSITY mathematics are created by human and, thus, the truth-value is also established by humans. 
Notes:

- Items $1=2,3=4 ; 5=6 ; 7=8$, but with different classes. Items 1 and 5 (about teaching) as well as 3 and 7 (about learning) for HA classes; Items 2 and 6 (about teaching) as well as 4 and 8 (about learning) for LA classes. As an example, see Figure 2.

- Items $9=10,11=12$, but with a different category of mathematics. Items 9 and 11 are for school mathematics and Items 10 and 12 are for university mathematics. As an example, see Figure 3.

- The rating scale for Items 1-8 is from absolutely not important to absolutely important (see Figure 2 as an example); it for Items 9-12 is from strongly disagree to strongly agree (see Figure 3 as an example).

The reason for using rank-then-rate items is firstly, as suggested by McCarty and Shrum (1997), to increase respondents' willingness to make differentiations and to reduce problems associated with social desirability (see Safrudiannur, 2020, for details). Secondly, to have a better insight into PSTs' beliefs, as research has shown that a teacher or a PST may have multiple beliefs which may be in conflict in a certain context. For instance, in the lesson of finding the area of a trapezoid (see Items 1 or 2 in Table 1), the PST may consider that giving many examples (A), or explaining concepts (B), or allowing students' strategies (C) are all necessary. However, in a certain class, (s)he may have priority order regarding what is most important. We expect that the rank procedure allows us to know the priority order.

1. When you have the lesson in a class dominated by HIGH-achieving students, what do you think that is important for YOU as a teacher?

\begin{tabular}{|c|c|c|c|c|c|c|c|c|c|}
\hline \multicolumn{10}{|c|}{ RANK } \\
\hline \multicolumn{10}{|c|}{$\begin{array}{l}\text { Please ORDER the three statements below by giving them a rank } 1 \\
\text { (the most), } 2 \text {, or } 3 \text { (the least). }\end{array}$} \\
\hline \multicolumn{7}{|c|}{ Statements } & \multicolumn{3}{|c|}{ Rank } \\
\hline \multirow{3}{*}{\multicolumn{7}{|c|}{$\begin{array}{l}\text { A. You demonstrate how to use the Area } \\
\text { formula correctly by giving some examples. } \\
\text { B. You explain concepts related how to get the } \\
\text { Area formula. } \\
\text { C. You let students find the area of a trapezoid } \\
\text { by their own ways. }\end{array}$}} & \multicolumn{3}{|c|}{2} \\
\hline & & & & & & & \multicolumn{3}{|c|}{1} \\
\hline & & & & & & & \multicolumn{3}{|c|}{3} \\
\hline \multicolumn{10}{|c|}{ RATE (based on your rank above) } \\
\hline \multicolumn{10}{|c|}{$\begin{array}{l}\text { Please RATE the level of importance of each statement. } \\
\text { Statements }\end{array}$} \\
\hline & & 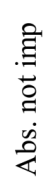 & 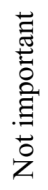 & 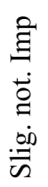 & 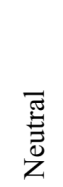 & 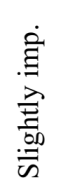 & 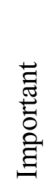 & 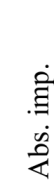 & \\
\hline \multirow{3}{*}{\multicolumn{2}{|c|}{$\begin{array}{ll}\text { A. } & \text { Statement A } \\
\text { B. } & \text { Statement B } \\
\text { C. } & \text { Statement C } \\
\end{array}$}} & $\mathrm{O}$ & $\mathrm{O}$ & $\mathrm{O}$ & $\mathrm{O}$ & $\odot$ & 0 & $\mathrm{O}$ & \\
\hline & & $\mathrm{O}$ & $\mathrm{O}$ & $\mathrm{O}$ & $\mathrm{O}$ & $\mathrm{O}$ & $\odot$ & $\mathrm{O}$ & \\
\hline & & $\mathrm{O}$ & $\mathrm{O}$ & $\odot$ & $\mathrm{O}$ & $\mathrm{O}$ & $\mathrm{O}$ & $\mathrm{O}$ & \\
\hline
\end{tabular}

2. When you have the lesson in a class dominated by LOW-achieving students, ...?

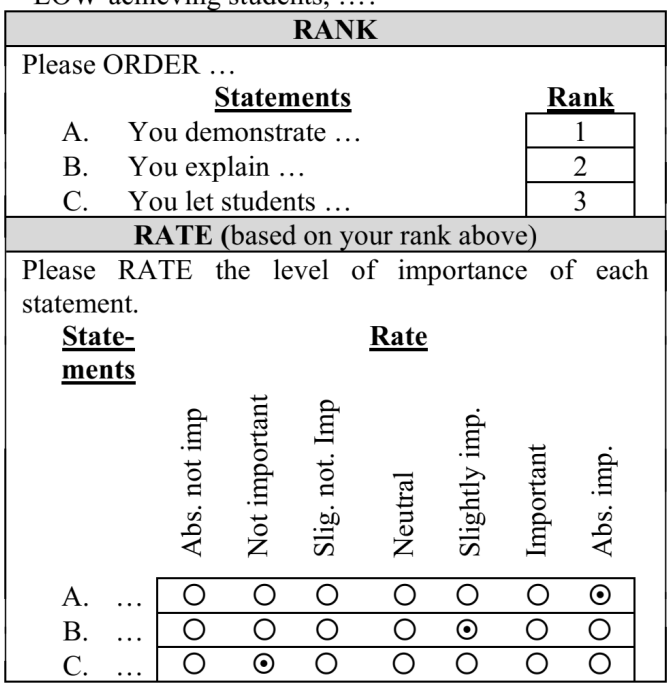

“...": see Item 1 for the complete sentences or words

Figure 2. Items 1 and 2 of the adapted TBTP and an example of a participant's responses

Furthermore, each item in Theme 1 is posed twice (for an example, see Figure 2): one time in an HA class and the other time in an LA class. The terms of HA and LA here are relative terms and "used in a somewhat loose way" (Zohar et al., 2001, p. 472). Following Zohar et al., we define HA and LA students as presented in the General Note in Table 1. Similarly, each item in Theme 2 is posed twice (as an example, see Figure 3): once for school mathematics and once for university mathematics. 


\section{Data Analyses}

Because of the use of rank-then-rate items, there will be two sets of data: ranking and rating data. We only use rating data for data analysis. The ranking data are not analysed because the role of the ranking part is only to psychologically force respondents to discriminate rates among statements before doing the rating (McCarty \& Shrum, 1997). By using statistical software JASP version 0.11 .1 developed by JASP Team (2019), we conducted Wilcoxon signed-rank test to answer the first and second research questions and Spearman's rho correlation to answer the third question. We formulate three hypotheses:

1. As we described in the introduction, previous studies found that teachers may differ how they teach mathematics between HA and LA classes. Like teachers, it is possible that PSTs think of the differentiation because of their experiences at school. Therefore, the first hypothesis (H1) is that "PSTs have different beliefs about mathematics teaching and learning between HA and LA classes".

2. As we described in the introduction, because of the different nature between school mathematics and university mathematics, previous studies found that university students may distinguish school mathematics from university mathematics. Therefore, the second hypothesis (H2) is "PSTs have different beliefs about the nature of school mathematics and university mathematics".

3. As we described in the introduction, previous studies found a strong relationship between beliefs about mathematics and beliefs about mathematics teaching and learning. Therefore, the third hypothesis (H3) is "There are correlations between beliefs about mathematics (school mathematics and university mathematics) and beliefs about teaching and learning in different contexts of students' achievements (in HA and LA classes)".

9. What do you think of the contents of SCHOOL mathematics? RANK

Please ORDER the three statements below by giving them a rank 1 (the most), 2 , or 3 (the least).

\section{Statements}

A. SCHOOL mathematics is an accumulation of facts, rules, and skills, which are useful for human life.

B. The contents of SCHOOL mathematics are interrelated and logically connected within an organisational structure.

C. Mathematics is a dynamic process of human activities. Thus, the contents of SCHOOL mathematics expand and change to accommodate new developments. RATE (based on your rank above)

Please RATE the level of your agreement to each statement. $\underline{\text { Statements }}$

Rate
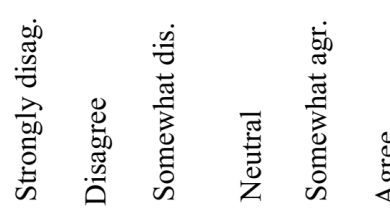

Rank

1

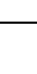

3

10. What do you think of the contents of UNIVERSITY mathematics?

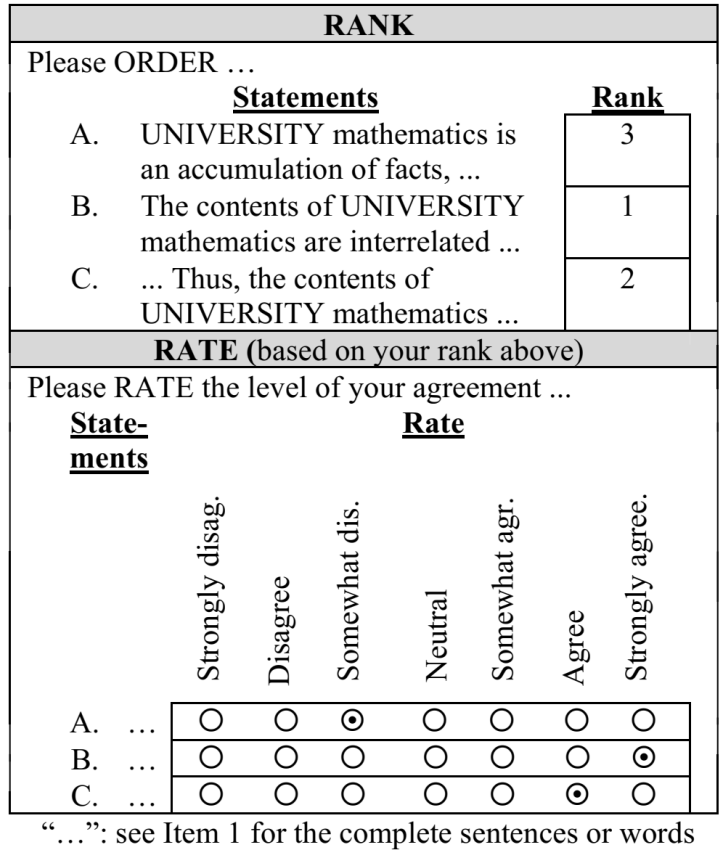
A. Statement A
B. Statement B
C. Statement C

\begin{tabular}{|ccccccc|}
\hline 0 & 0 & 0 & 0 & 0 & 0 & $\odot$ \\
\hline 0 & 0 & 0 & 0 & $\odot$ & 0 & 0 \\
\hline 0 & $\odot$ & 0 & 0 & 0 & 0 & 0 \\
\hline
\end{tabular}

Figure 3. Items 9 and 10 of the adapted TBTP and an example of a participant's responses 


\section{Findings and Discussion}

We discuss this section by answering our research questions. We report the calculation of alpha coefficients of the revised TBTP as a start. Since the TBTP is inspired by the Diversity Icebreaker questionnaire from Ekelund, Pluta, and Ekelund (2013) we follow their reports about the alpha coefficients of their questionnaire. Table 2 shows that alpha coefficients for each view are acceptable because of above 0.7 (Ekelund, et al., 2013; Field, 2005).

Table 2. The Cronbach's alpha coefficients of each view

\begin{tabular}{llc}
\hline \multicolumn{1}{c}{ Views } & \multicolumn{1}{c}{ Statements } & Cronbach's $\boldsymbol{\alpha}$ \\
\hline Instrumentalist & All statements A from Item 1 to Item 20 & 0.780 \\
Platonist & All statements B from Item 1 to Item 20 & 0.735 \\
Problem solving & All statements C from Item 1 to Item 20 & 0.808 \\
\hline
\end{tabular}

\section{Do PSTs have different beliefs about teaching and learning in different contexts of students' achievements?}

We present respondents' rates to items of Theme 1 in Table 3. The table shows several significant differences ( $\mathrm{H} 1$ can be accepted).

Table 3. The results of Wilcoxon signed-rank tests: the comparison of beliefs

\begin{tabular}{|c|c|c|c|c|c|}
\hline Beliefs & $\begin{array}{l}\text { Statistic } \\
\text { Views }\end{array}$ & $\begin{array}{r}\text { Mean (Stand } \\
\qquad=1\end{array}$ & $\begin{array}{l}\text { rd Deviation) } \\
06\end{array}$ & Statistic & $\begin{array}{l}\text { Sig. (2- } \\
\text { tailed) }\end{array}$ \\
\hline Beliefs about & & HA class & LA class & & \\
\hline teaching and & Instrumentalist & $5.171(0.822)$ & $6.103(0.581)$ & 801.500 & $<.001 *$ \\
\hline learning of & Platonist & $6.232(0.708)$ & $6.234(0.733)$ & 7881.000 & 0.903 \\
\hline $\begin{array}{l}\text { mathematics } \\
\text { (Theme 1) }\end{array}$ & $\begin{array}{l}\text { Problem- } \\
\text { solving }\end{array}$ & $5.197(0.898)$ & $4.256(0.946)$ & 14958.500 & $<.001 *$ \\
\hline Beliefs about & & School math. & Univ. math. & & \\
\hline mathematics & Instrumentalist & $6.041(0.773)$ & $5.796(0.913)$ & 8399.5 & $0.002 *$ \\
\hline (Theme 2) & Platonist & $5.478(0.797)$ & $5.663(0.814)$ & 3988.0 & $0.004 *$ \\
\hline & $\begin{array}{l}\text { Problem- } \\
\text { solving }\end{array}$ & $4.954(0.923)$ & $5.039(0.963)$ & 4584.5 & 0.200 \\
\hline
\end{tabular}

Table 3 shows significant differentiations in the instrumentalist view. The rates reflect that styles of teaching and learning associated with this view are more important for students in LA classes than for students in HA classes. However, although there are differentiations between HA and LA classes, we need to be careful to translate the differentiation. The mean rates 5.171 for teaching and learning (close to slightly important) in HA classes and 6.103 (close to important) in LA classes indicate that styles of teaching and learning associated with the instrumentalist view are appropriate for both HA and LA classes.

Table 3 shows no significant differences in the Platonist view. No significant differences mean that the participant of this study consider that styles of teaching and learning associated with the Platonist view are important for both HA and LA classes (all mean rates associated with the Platonist view are close to important).

Further, Table 3 shows that PSTs participating in this study significantly differ their rates to statements associated with the problem-solving view between HA and LA classes. The rates seem to reflect that teaching and learning associated with the problem-solving view are 
considered to be more appropriate for HA classes (the mean rate 5.175 is close to slightly important), but less appropriate for LA classes (the mean rate 4.256 is close to neutral).

Regarding the differentiation of teaching and learning between HA and LA classes, previous studies, for example, Raudenbush, Rowan, and Cheong (1993), Safrudiannur and Rott (2021) as well as Zohar, et. al. (2001), found that some teachers are more likely to teach with higher order thinking processes such as use problem solving and supporting thinking-based learning to actively develop students' knowledge (associated with the problem-solving view) in HA classes more than in LA classes. The teachers feel that teaching with higher order thinking processes is not appropriate for LA classes. For LA classes, only teaching with low order thinking processes such as giving transmission of knowledge by direct instruction and drilling after the transmission to ensure students to be able to master knowledge (associated with the instrumentalist view) is appropriate.

The results of our study seem to support the results of the previous studies. PSTs participating in this study also consider styles of teaching and learning associated with the problem-solving view to be appropriate for HA classes and seem to not think of them as being appropriate for LA classes (see Table 3). For LA classes, they consider that styles of teaching and learning associated with the instrumentalist view are appropriate. However, our study found that PSTs still consider the appropriateness of teaching styles associated with the instrumentalist view for HA classes. It means that they will still use the styles associated with the instrumentalist view to teach mathematics not only in LA classes but also in HA classes. Further, our study also found that styles of teaching and learning with the Platonist view are important for both HA and LA classes. It means that giving explanations and students' understanding are necessary for HA and LA classes, supporting the argument from Van de Walle, Bay-Williams, Lovin \& Karp (2013) that most teachers want their students to be able to understand the contents of what they teach.

\section{Do PSTs have different beliefs about school mathematics and university mathematics?}

Table 3 also presents the participants rates to items of Theme 2 and shows several significant differences (H2 can be accepted). These results indicate the possibility that pre-service teachers may differ their views about school mathematics and university mathematics.

Interestingly, although Table 3 shows that PSTs significantly differ their rates between school mathematics and university mathematics, the mean rates of both of them are the highest (both are close to agree). Apparently, it indicates that participants who hold the instrumentalist view of school mathematics tend to also hold the instrumentalist view of university mathematics. It seems that they still see university mathematics as a collection of facts.

The fact that many PSTs still see university mathematics as a collection of facts should not be a surprise for us because of the overall presentation of university mathematics. Generally, university mathematics is presented as a set of definitions and theorems, and to do proofs, university students must use the definitions and theorems strictly. In the sense of Hersh (1991), the presentation shows the front face of mathematics. Mathematics is shown in "finished form" (p. 128), the form which we see often in university mathematics textbooks and journals. Geisler and Rolka (2021) argue that presenting the front face of mathematics could be related to the phenomenon why university students see university mathematics in a static view (associated with the instrumentalist view). 
Similar to the instrumentalist view, there is a significant difference in the Platonist view. PSTs seem to see that school mathematics is less interrelated than university mathematics. In contrast to the instrumentalist view and the Platonist view, there is no significant difference in the problem-solving view. They somewhat agree that both school mathematics and university mathematics are human processes in solving problems. Perhaps, the presentation of school mathematics and university mathematics which looks like emphasizing the importance of facts, formulas, definitions, and theorems causes PSTs to see mathematics as human processes.

\section{Are there correlations between PSTs' beliefs about mathematics and their beliefs about teaching and learning of mathematics?}

As we described in the introduction, previous research has shown a significant relationship between beliefs about the nature of mathematics and beliefs about teaching and learning mathematics. The results of our studies support this relationship. Table 4 shows several correlations between PSTs' beliefs about mathematics and beliefs about teaching and learning (H3 can be accepted).

There is an assumption that teachers' beliefs about teaching and learning in the context of their classroom are more influenced by their beliefs about school mathematics than by their beliefs about mathematics as a discipline (Beswick, 2012), i.e. university mathematics. The results of our study indicate that the assumption does not take place in PSTs' beliefs - maybe because their beliefs about school mathematics are not strong enough, yet, due to missing teaching experiences. In HA classes, both beliefs about school mathematics and university mathematics correlate with beliefs about teaching and learning of mathematics. In LA classes and especially for the instrumentalist view, beliefs about university mathematics seem to have better correlation than do beliefs about school mathematics. These results indicate that beliefs about university mathematics may be a better predictor for beliefs about teaching and learning in different contexts of students' achievements than beliefs about school mathematics.

Table 4. The results of the Spearman's rho correlations between beliefs

\begin{tabular}{llcc}
\hline Views & \multicolumn{1}{c}{$\begin{array}{c}\text { Beliefs about } \\
\text { mathematics } \\
\text { (Theme 2) }\end{array}$} & \multicolumn{2}{c}{$\begin{array}{c}\text { Beliefs about teaching and learning of } \\
\text { mathematics } \\
\text { (Theme 1) }\end{array}$} \\
\cline { 3 - 4 } & & in HA class & in LA class \\
\hline Instrumentalist & School math & $0.217^{* *}$ & 0.057 \\
& University math & $0.211^{*}$ & $0.278^{* * *}$ \\
\hline Platonist & School math & $0.287^{* * *}$ & -0.011 \\
& University math & $0.184^{* *}$ & -0.015 \\
\hline \multirow{2}{*}{ Problem-solving } & School math & $0.204^{* *}$ & $0.176^{*}$ \\
& University math & $0.298^{* * *}$ & $0.222^{* *}$ \\
\hline
\end{tabular}

$* p<.05, * * p<.01, * * * p<.001$

\section{Conclusion, implication and limitation}

Overall, the results of our study show that it is possible for PSTs to hold different beliefs about mathematics teaching and learning in different contexts of students' achievements. They seem to consider that styles of teaching and learning associated with the instrumentalist view, the Platonist view, and the problem-solving view are appropriate for HA classes. Whereas, for LA classes, only styles of teaching and learning associated with the instrumentalist view and the 
Platonist view are appropriate. For the PSTs, those associated with the problem-solving view are not appropriate for LA classes.

The results of our study also show the possibility that PSTs may have different beliefs about school mathematics and university mathematics. Interestingly, the results indicate that beliefs about university mathematics seem to have a better correlation with beliefs about teaching and learning than do beliefs about school mathematics. These results give us hope to change PSTs beliefs about teaching and learning during their university studies. In other words, these results imply the important role of mathematics lectures for teacher education at universities as it is here that PSTs develop their beliefs about mathematics. As Cross (2009) suggests that beliefs about mathematics teaching and learning are built from what PSTs beliefs about mathematics.

As shown in Table 4, beliefs about university mathematics in the dimension of the instrumentalist view and the problem-solving view have positive correlations with their beliefs about teaching and learning in both HA and LA classes. If we consider that beliefs about teaching and learning associated with the problem-solving view give much benefit and those associated with the instrumentalist view give little benefit for mathematics education, then mathematics in lectures should be presented as a process of mathematicians in solving problems rather than a toolbox consisting of many formulas which are ready to be used to solve the problems. Moreover, we need to present the backface of university mathematics rather than the front face of it (see Hersh, 1991), for example, inviting PSTs to construct rather than presenting the theorems directly.

The last, although the results of this study imply the significant things for mathematics education, we note a limitation. All PSTs participating in this study are from the department of mathematics education of one university. As we know, there are many departments of mathematics education of other universities which may have different mathematics courses and curricula. Therefore, the characteristics of PSTs' beliefs may be different between universities. Therefore, comparing PSTs from different universities may give us better insights regarding their beliefs about mathematics and their beliefs about teaching and learning mathematics.

\section{References}

Beswick, K. (2012). Teachers' beliefs about school mathematics and mathematicians' mathematics and their relationship to practice. Educational Studies in Mathematics, 79(1), 127-147. Doi: 10.1007/s10649-011-9333-2

Beswick, K. (2018). Systems perspectives on mathematics teachers' beliefs: Illustrations from beliefs about students. In E. Bergvist, M. Österhom, C. Granberg \& L. Sumpter (Eds.). Proceedings of the 42nd Conference of the International Group for the Psychology of Mathematics Education (Vol. 1, pp. 3-18). Umeå, Sweden: PME.

Briley, J. S. (2012). The relationships among mathematics teaching efficacy, mathematics self-efficacy, and mathematical beliefs for elementary pre-service teachers. Issues in the Undergraduate Mathematics Preparation of School Teachers: The Journal, 5, 1-13.

Buehl, M. M. \& Beck, J. S. (2015). The relationship between teachers' beliefs and teachers' practices. In H. Fives and M. G. Gill (Eds.), International Handbook of Research on Teachers' Beliefs, (pp. 6684). New York: Routledge.

Cross, D. I. (2009). Alignment, cohesion, and change: Examining mathematics teachers' belief structures and their influence on instructional practices. Journal of Mathematics Teacher Education, 12(5), 325 346. Doi:10.1007/s10857-009-9120-5

Dede, Y. \& Uysal, F. (2012). Examining Turkish preservice elementary teachers' beliefs about the nature and the teaching of mathematics. International Journal of Humanities and Social Science, 2(12), 125135 . 
Di Martino, P. \& Gregorio, F. (2019). The mathematical crisis in secondary-tertiary transition. International Journal of Science and Mathematics Education, 17(4), 825-843. Doi:10.1007/s10763018-9894-y

Dionne, J. (1984). The perception of mathematics among elementary school teachers. In J. Moser (Ed.), Proceedings of the 6th Annual Meeting of the North American Chapter of the International Group for the PME (pp. 223-228). Madison (WI): University of Wisconsin.

Ekelund, B. Z., Pluta, P., \& Ekelund, H. K. (2013). Documentation for description and evaluation of the Diversity Icebreaker. Retrieved from https://diversityicebreaker.com/ Admin/Public/Download.aspx?file=Files\%2FFiler\%2FDNV\%2FDiversity+Icebreaker+-

+ Documentation + for + description+and + evaluation $+6+12+2013+v 3 . p d f$

Ernest, P. (1989a). The impact of beliefs on the teaching of mathematics. In P. Ernest (Ed.), Mathematics teaching: The state of the art (pp. 249-254). London: Falmer Press.

Ernest, P. (1989b). The knowledge, beliefs and attitudes of the mathematics teacher: a model. Journal of Education for Teaching: International research and pedagogy, 15(1), 13-33. Doi:10.1080/0260747890150102

Field, A. (2005). Discovering statistics using SPSS (3rd ed.). London, England: Sage Publication Ltd.

Geisler, S. \& Rolka, K. (2018). Affective variables in the transition from school to university mathematics. In V. Durand-Guerrier, R. Hochmuth, S. Goodchild \& N. M. Hogstad (Eds.), Proceedings of the Second Conference of the International Network for Didactic Research in University Mathematics (pp. 507-516). Kristiansand, Norway: University of Agder and INDRUM.

Geisler, S. \& Rolka, K. (2021). "That wasn't the math I wanted to do!'-students' beliefs during the transition from school to university mathematics. International Journal of Science and Mathematics Education, 19, 599-618. Doi:10.1007/s10763-020-10072-y

Hersh, R. (1991). Mathematics has a front and a back. Synthese, 88(2), 127-133.

JASP Team. (2019). JASP(Version 0.11.1) [Computer software]. Retrieved from http://jaspstats.org/download/

Larina, G. \& Markina, V. (2020). Hidden mechanisms of differentiation: teachers' beliefs about student diversity. Journal of Mathematics Teacher Education, 23(5), 463-482. Doi:10.1007/s10857-01909436-1

Leatham, K. R. (2006). Viewing mathematics teachers' beliefs as sensible systems. Journal of Mathematics Teacher Education, 9(1), 91-102. Doi:10.1007/s10857-006-9006-8

Leong, Y. H., Cheng, L. P., Toh, W. Y. K., Kaur, B. \& Toh, T. L. (2021). Teaching students to apply formula using instructional materials: a case of a Singapore teacher's practice. Mathematics Education Research Journal, 33(1), 89-111. Doi:10.1007/s13394-019-00290-1

McCarty, J. A. \& Shrum, L. J. (1997). Measuring the importance of positive constructs: A test of alternative rating procedures. Marketing Letters, 8(2), 239-250. Doi:10.1023/A:1007918705434

Pajares, M. F. (1992). Teachers' beliefs and educational research: Cleaning up a messy construct. Review of Educational Research, 62(3), 307-332. Doi:10.3102/00346543062003307

Philipp, R. A. (2007). Mathematics teachers' beliefs and affect. In F. K. Lester (Ed.), Second handbook of research on mathematics teaching and learning: A project of the national council of teachers of mathematics (pp. 257-315). Charlotte: Information Age Publishing.

Raymond, A. M. (1997). Inconsistency between a beginning elementary school teacher's mathematics beliefs and teaching practice. Journal for Research in Mathematics Education, 28(5), 550-576. Doi: $10.2307 / 749691$

Raudenbush, S. W., Rowan, B., \& Cheong, Y. F. (1993). Higher order instructional goals in secondary school: Class, teacher and school influences. American Educational Research Journal, 30(3), 523553. Doi:10.3102/00028312030003523

Rejeki, S. \& Sugiyanti. (2015). Pre-service teachers' beliefs about mathematics. Proceedings of the International Conference on Science, Technology and Humanity, Volume 1 (pp. 344-350). Surakarta.

Safrudiannur. (2020). Measuring teachers' beliefs quantitatively: Criticizing the use of Likert Scale and offering a new approach. Wiesbaden: Springer Spektrum. Doi:10.1007/978-3-658-30023-4

Safrudiannur \& Rott, B. (2018). Evaluation of a questionnaire for studying teachers' beliefs on their practice (TBTP). In B. Rott, G. Törner, J. Peters-Dasdemir, A. Möller \& Safrudiannur (Eds.), Views and beliefs in mathematics education: The role of beliefs in the classroom (pp. 207-220). Springer. Doi:10.1007/978-3-030-01273-1_19 


\section{Safrudiannur et al.}

Safrudiannur \& Rott, B. (2019). Capturing how students' abilities and teaching experiences affect teachers' beliefs about mathematics teaching and learning. Teaching Mathematics and Computer Science, 17(2), 195-212. Doi:10.5485/TMCS.2019.0465

Safrudiannur \& Rott, B. (2021). Offering an approach to measure beliefs quantitatively: Capturing the influence of students' abilities on teachers' beliefs. International Journal of Science and Mathematics Education, 19(2), 419-441. Doi:10.1007/s10763-020-10063-z

Schoenfeld, A. H. (2015). What counts, when? Reflection on beliefs, affect, attitude, orientations, habits of mind, grain size, time scale, context, theory, and method. In B. Pepin and B. Roesken-Winter (Eds.), From beliefs to dynamic affect systems in mathematics education (pp. 395-404). Switzerland: Springer International.

Tall, D. (2008). The transition to formal thinking in mathematics. Mathematics Education Research Journal, 20(2), 5-24. Doi:10.1007/BF03217474

Thompson, A. G. (1992). Teachers' beliefs and conceptions: A synthesis of the research. In D. A. Grouws (Ed.), Handbook of research on mathematics teaching and learning: A project of NCTM (pp. 127146). New York, NY, England: Macmillan Publishing Co, Inc.

Törner, G. \& Pehkonen, E. (1998). Teachers' beliefs on mathematics teaching-comparing different selfestimation methods - A case study. Retrieved from https://duepublico.uni-duisburgessen.de/servlets/DerivateServlet/Derivate-5246/mathe91999.pdf.

Van de Walle, J. A., Bay-Williams, J. M., Lovin, L. H., \& Karp, K. S. (2013). Teaching student-centered mathematics: Developmentally appropriate instruction for grades 6-8 (Vol. III, 2nd ed.). Essex, England: Pearson Education.

Zakaria, E. \& Musiran, N. (2010). Beliefs about the nature of mathematics, mathematics teaching and learning among trainee teachers. The Social Sciences, 5(4), 346-351. Doi:10.3923/sscience.2010.346.351

Zohar, A., Degani, A., \& Vaaknin, E. (2001). Teachers' beliefs about low-achieving students and higher order thinking. Teaching and Teacher Education, 17(4), 469-485. Doi:10.1016/S0742051X(01)00007-5 